\title{
Whole Linted Cottonseed as a Forage Substitute Fed with Ground or Steam-flaked Corn: Digestibility and Performance ${ }^{1,2}$
}

\author{
D. I. Harvatine, ${ }^{3}$, J. L. Firkins, and M. L. Eastridge \\ Department of Animal Sciences, \\ The Ohio State University, Columbus, 43210
}

\begin{abstract}
Six ruminally and duodenally cannulated Holstein cows were used in a $6 \times 6$ Latin square design. The objective was to evaluate any potential interactions in site of nutrient digestion when neutral detergent fiber (NDF) from cottonseed was incrementally substituted for forage NDF (FNDF) from alfalfa silage and when starch availability was varied by feeding ground $(\mathrm{G})$ or steam-flaked (SF) corn. Iso-NDF diets were forage control with G corn (21\% FNDF), 5\% whole cottonseed (WCS) with G or SF corn (18\% FNDF), 10\% WCS with G or SF corn (15\% FNDF), and 15\% WCS with G corn (12\% FNDF). Ruminal or total tract digestibilities of organic matter (OM) or nonstructural carbohydrate (NSC) were unaffected, but efficiency of microbial protein synthesis decreased as WCS increased. Ruminal NDF digestibility was not affected despite a linear decrease in $\mathrm{pH}$, but postruminal NDF digestibility decreased with increasing WCS. Ruminal digestibilities of OM and NSC were higher for SF than G corn but did not affect efficiency of microbial $\mathrm{N}$ synthesis. Dry matter intake increased quadratically with increasing level of WCS but decreased when SF replaced G corn. Milk yield did not differ across treatments. Milk fat percentage was affected quadratically and milk protein increased linearly with increasing WCS. Milk fat percentage decreased but milk protein was not affected when SF replaced G corn. Lack of an interaction between corn source and level of WCS substitution suggests that WCS was equally effective in maintaining ruminal fermentation and digestibility in diets varying in ruminal starch availability.
\end{abstract}

\footnotetext{
Received June 8, 2001.

Accepted February 2, 2002.

Corresponding author: J. L. Firkins; e-mail: firkins.1@osu.edu.

${ }^{1}$ Salaries and research support were provided by state and federal funds appropriated to the Ohio Agricultural Research and Development Center, The Ohio State University. Manuscript number 15-

${ }^{2}$ Additional research support was provided by the Ohio Dairy Farmers Federation Dairy Research Fund; Pennfield Feeds, Lancaster, PA; and Cotton Incorporated, Cary, NC.

${ }^{3}$ Current Address: Agway Feed and Nutrition, 512 West King St, Shippensburg, PA 17257.
} $01 \mathrm{AS}$.
(Key words: corn processing, starch digestion, fiber digestion, whole cottonseed)

Abbreviation key: ADIN = acid detergent insoluble N, FCG = forage control with ground corn, FNDF = forage $\mathrm{NDF}, \mathbf{G}=$ ground corn, $\mathbf{H G}=$ high cottonseed with ground corn, $\mathbf{L G}=$ low cottonseed with ground corn, $\mathbf{L S F}=$ low cottonseed with steam-flaked corn, $\mathbf{M G}$ $=$ medium cottonseed with ground corn, $\mathbf{M S F}=$ medium cottonseed with steam-flaked corn, NDIN = neutral detergent insoluble N, NFFS = nonforage fiber source, $\mathbf{S F}=$ steam-flaked corn, $\mathbf{W C S}=$ whole cottonseed.

\section{INTRODUCTION}

Grain processing increases ruminal starch availability (Theurer et al., 1999). The combined effects of heat, steam, and pressure during steam-flaking increase starch availability by disrupting the protein matrix surrounding the starch granule and by gelatinizing the starch (Theurer et al., 1999). Increased ruminal starch availability has negatively affected NDF digestibility (Poore et al., 1993a; Plascencia and Zinn, 1996; Joy et al., 1997) and efficiency of microbial protein synthesis (Firkins, 1996) due to low ruminal pH (Russell, 1998). To maintain ruminal $\mathrm{pH}$, the increased production of fermentative acids must be balanced with physically effective fiber to minimize negative associative effects from rapid ruminal starch degradability (Allen, 1997).

The previous NRC (1989) suggested that $75 \%$ of the dietary fiber should be provided as forage, which is equivalent to $21 \%$ of DM as forage NDF (FNDF). Although the current NRC (2001) suggests that minimum FNDF can be decreased when dietary NSC concentration is decreased, improved quantification of the effectiveness of forage and nonforage fiber sources (NFFS) would reduce variation in ration formulations. Replacement of NDF from NFFS for FNDF has reduced DMI when FNDF decreased below 14 to 16\% (Firkins, 1997), but lactation performance was maintained in diets with 11 to $12 \%$ FNDF when whole cottonseed (WCS) replaced forage and when nonfiber carbohydrate was simultaneously reduced by WCS and other NFFS (Clark and Armentano, 1997; Slater et al., 2000). Replacing 
starch sources with NFFS increased ruminal pH (Swain and Armentano, 1994; Firkins, 1997), but some NFFS had low NDF digestibility when substituted for forage, apparently because of faster passage rates and slower digestion rates (Firkins, 1997). Despite the common usage of WCS as a forage substitute, site and extent of WCS digestion have not been extensively evaluated when WCS was fed as a forage replacement.

Although soybean hulls (Weidner and Grant, 1994) and wet corn gluten feed (Allen and Grant, 2000) interacted with forage to alter passage rate, NDF effectiveness, and digestibility, the potential interaction of WCS and forage have not been researched adequately. Because WCS appears to be the most effective NFFS source but its effectiveness varied inversely with the effectiveness of the forage (Mooney and Allen, 1997), high levels of WCS may not be effective enough to maintain ruminal $\mathrm{pH}$ and digestibility in diets higher in ruminal starch availability. Thus, our objectives were to evaluate potential interactions in site of nutrient digestion and lactation performance as WCS replaced forage and when steam-flaked (SF) or ground $(\mathbf{G})$ corn was fed.

\section{MATERIALS AND METHODS}

\section{Animals, Treatments, and Experimental Design}

Six primiparous Holstein cows were fitted with ruminal and simple $\mathrm{T}$ duodenal cannulas as per approved animal care and use guidelines. At the start of the experiment, cows were 130, 134, 137, 140, 161, and 28 DIM. The sixth cow was used as a replacement for one cow that died of complications at calving, and one cow was removed from the final collection period due to duodenal cannula complications. Cows were injected with Posilac (Monsanto, St. Louis, MO), a synthetic bST, every 2 wk throughout the trial except for the replacement, which never received Posilac during the trial. The first Posilac injection was given 2 wk before the initiation of the trial.

All six experimental diets (Table 1 ) were alfalfa silage-based TMR included as treatments in a $6 \times 6$ Latin square. Diets were balanced to be equivalent in nutrient composition on a DM basis (28\% NDF, $5.6 \%$ lipid, $19 \%$ $\mathrm{CP}, 12 \% \mathrm{RDP}$, and $1.67 \mathrm{Mcal} / \mathrm{kg}$ of $\mathrm{NE}_{\mathrm{L}}$ based on reference values). The RDP concentration was balanced using estimates from Spartan Ration Evaluator (VandeHaar et al., 1992). The forage control diet (FCG) with no WCS addition contained the NRC (1989) recommendation of $21 \%$ FNDF. The WCS diets contained linted WCS at low, medium, or high concentrations $(5,10$, and $15 \%$ of dietary DM, respectively). In a review, Arieli (1998) recommended a maximal WCS inclusion rate of $15 \%$ of dietary DM. In diets with G corn, alfalfa silage was replaced with WCS on an NDF basis to achieve diets with $18 \%$ FNDF (LG), 15\% FNDF (MG), and $12 \%$ FNDF (HG). Linted cottonseed hulls were added to the diets in slightly different amounts during each period to balance NDF from forage and WCS and to enable the direct substitution of alfalfa silage NDF with cotton products (WCS plus cottonseed hulls) NDF, allowing $\mathrm{NFC}$ to be equivalent and reducing the potential effect of a grain dilution response (Armentano and Pereira, 1997). To evaluate the potential interaction of starch availability and level of forage substitution, the $G$ in the LG and MG diets was replaced with SF (LSF and MSF diets). Steam-flaked corn (7.94\% CP, 9.96\% NDF, and $2.72 \%$ FA on DM bases) was provided by Pennfield Feeds, Lancaster, Pennsylvania. The density according to the manufacturing specifications $(0.360$ to $0.386 \mathrm{~kg} /$ L of $85 \%$ DM corn) was slightly lower than our measurement $(0.393 \mathrm{~kg} / \mathrm{L}$ on DM basis) probably because of corn fracture during handling and storage. Ground corn (7.56\% CP, $13.1 \% \mathrm{NDF}$, and $4.66 \% \mathrm{FA}$ on DM bases) had a mean particle size of $1.05 \mathrm{~mm}$. Mean particle size was determined according to log-normal distribution procedures after dry sieving (Kerley et al., 1985). Cotton Incorporated, Cary, North Carolina, provided the WCS (23.6\% CP, $48.7 \% \mathrm{NDF}$, and $18.4 \% \mathrm{FA})$ and cottonseed hulls $(6.31 \% \mathrm{CP}, 84.2 \% \mathrm{NDF}$, and $2.88 \% \mathrm{FA})$. Roasted soybeans were heated as described by Tice et al. (1993) and cracked. Alfalfa silage (19.2\% CP and $40.6 \% \mathrm{NDF}$ ) had a mean particle size of $5.64 \mathrm{~mm}$, with $38.5,53.9$, 66.5 , and $72.8 \%$ retained on screens with pore sizes of $9.5,4.75,2.36$, and $1.18 \mathrm{~mm}$, respectively, after wet sieving (Kerley et al., 1985).

\section{Sampling and Laboratory Analysis}

Periods consisted of $21 \mathrm{~d}$, with $\mathrm{d} 1$ through 9 serving as an adjustment period; and d 10 through 21, as the data collection period. Diets were prepared once daily as a TMR and fed twice daily in equal proportions at 0600 and $1800 \mathrm{~h}$ ad libitum. Orts were weighed daily at $1600 \mathrm{~h}$ to adjust feed offered for $10 \%$ refusal. Feed offered and individual dietary components were sampled on d 13 through 17, and orts were sampled on d 14 through 18. Samples were composited by cow, sample type, and period and were lyophilized.

Cows were housed in a conventional tie-stall barn with mattresses. They were allowed access to a concrete lot before milking, except on days when chewing activity was being monitored (Harvatine et al., 2002). Cows were milked at 0530 and $1600 \mathrm{~h}$ daily, with milk yield recorded at each milking. Milk samples were taken at a.m. and p.m. milkings on d 14 to 16 of each period and analyzed by DHI Cooperative Inc. (Powell, OH) for milk fat and CP by infrared spectroscopy and for milk urea 
Table 1. Ingredient composition of experimental diets.

\begin{tabular}{|c|c|c|c|c|c|c|}
\hline \multirow[b]{2}{*}{ Ingredient } & \multicolumn{6}{|c|}{$\operatorname{Diets}^{1}$} \\
\hline & FCG & LG & MG & HG & LSF & MSF \\
\hline & \multicolumn{6}{|c|}{ $\%$ of $\mathrm{DM}$} \\
\hline Alfalfa silage & 53.00 & 44.70 & 38.00 & 30.27 & 44.70 & 38.00 \\
\hline Whole linted cottonseed & $\ldots$ & 5.00 & 10.00 & 15.00 & 5.00 & 10.00 \\
\hline Cottonseed hulls & $\ldots$ & 0.65 & 0.93 & 1.43 & 0.65 & 0.93 \\
\hline Corn, ground shelled & 27.72 & 30.44 & 32.59 & 35.19 & $\ldots$ & \\
\hline Corn, steam-flaked & $\ldots$ & & & & 30.44 & 32.59 \\
\hline Soybean meal, $48 \% \mathrm{CP}$ & $\ldots$ & 3.63 & 7.36 & 11.16 & 3.63 & 7.36 \\
\hline Roasted soybeans, cracked & 14.41 & 9.89 & 4.94 & $\ldots$ & 9.89 & 4.94 \\
\hline Soybean hulls & 2.13 & 2.64 & 2.86 & 3.35 & 2.64 & 2.86 \\
\hline Soybean hull pellets ${ }^{2}$ & 1.10 & 1.10 & 1.10 & 1.10 & 1.10 & 1.10 \\
\hline Trace-mineralized salt ${ }^{3}$ & 0.48 & 0.49 & 0.49 & 0.50 & 0.49 & 0.49 \\
\hline Monosodium phosphate & 0.64 & 0.66 & 0.66 & 0.67 & 0.66 & 0.66 \\
\hline Magnesium oxide & 0.09 & 0.09 & 0.09 & 0.09 & 0.09 & 0.09 \\
\hline Limestone & 0.32 & 0.59 & 0.86 & 1.12 & 0.59 & 0.86 \\
\hline Vitamin premixes $^{4}$ & 0.11 & 0.12 & 0.12 & 0.12 & 0.12 & 0.12 \\
\hline \multicolumn{7}{|c|}{$\begin{array}{l}{ }^{1} \mathrm{FCG}=\text { Forage control with ground corn; } \mathrm{LG}=\text { low cottonseed with ground corn; } \mathrm{MG}=\text { medium cottonseed } \\
\text { with ground corn; } \mathrm{HG}=\text { high cottonseed with ground corn; } \mathrm{LSF}=\text { low cottonseed with steam-flaked corn, } \\
\text { and MSF = medium cottonseed with steam-flaked corn. }\end{array}$} \\
\hline \multicolumn{7}{|c|}{${ }^{2}$ Contained $5 \%$ chromic oxide. } \\
\hline 100, I; 60, Se, and 50, Co. & & & & & 2000, & \\
\hline
\end{tabular}

$\mathrm{N}$ using a Skalar SAN Plus segmented flow analyzer (Skalar, Inc., Norcross, GA). Daily milk fat and protein yields were calculated and averaged by cow per period. Cows were weighed prior to the p.m. milking on $d 7$, 14 , and 21 of each period; BW were averaged per period.

Core samples (approximately $600 \mathrm{ml}$ ) of ruminal contents from three different sites in the rumen were removed at 3, 6, 9, and $12 \mathrm{~h}$ after the a.m. feeding on $\mathrm{d}$ 14 of each period. Contents were strained through two layers of cheesecloth, and $\mathrm{pH}$ of the fluid was measured immediately. A 50-ml aliquot of the filtered ruminal fluid was acidified with $3 \mathrm{ml}$ of $6 \mathrm{~N} \mathrm{HCl}$ to stop fermentation and frozen. After thawing, the acidified ruminal fluid was mixed, centrifuged at $15,000 \times g$ at $4^{\circ} \mathrm{C}$ for $15 \mathrm{~min}$, and then filtered through Whatman number 1 filter paper (Whatman, Clifton, NJ). The supernatant was analyzed for VFA concentrations by GLC (Pantoja et al., 1994) and for $\mathrm{NH}_{3} \mathrm{~N}$ (Chaney and Marbach, 1962).

Digestibility was measured on d 14 to 17 of each period. A pellet (equivalent to $1.1 \%$ of daily DMI) containing 5\% $\mathrm{Cr}_{2} \mathrm{O}_{3}$ and $95 \%$ soybean hulls was dosed through the rumen cannula twice daily on $\mathrm{d} 8$ through 17. Fecal grab samples were taken on d 14 to 17 of each period so that every $3 \mathrm{~h}$ in a 24 -h period were represented (eight samples total). Samples were dried in a forced-air oven at $40^{\circ} \mathrm{C}$ for 48 to $60 \mathrm{~h}$. Samples were composited on an air-dry basis by cow within period. Duodenal samples $(250 \mathrm{ml})$ were taken on $\mathrm{d} 14$ to 17 of each period so that every $90 \mathrm{~min}$ in a 24 -h period were represented (16 samples total), combined by cow within period, and frozen immediately. After thawing, a 1000-ml subsample of the composited duodenal contents was lyophilized.

The samples of feed offered, orts, individual dietary components, and duodenal contents were ground to pass through a 2-mm screen (Wiley Mill; Arthur H. Thomas, Philadelphia, PA). The chromic oxide pellets were composited by period and ground manually using a mortar and pestle. Samples of feed, orts, chromic oxide pellets, duodenal contents, and fecal contents were analyzed for DM, OM, and N (AOAC, 1990). The NDF concentration of feed, orts, chromic oxide pellets, duodenal samples, and fecal samples was determined according to Van Soest et al. (1991) using hot ethanol, $8 M$ urea, and heat stable $\alpha$-amylase (Sigma A3306; Sigma Chemical Co., St. Louis, MO). The ADF and acid-detergent lignin concentrations of feed offered and chromic oxide pellets were determined sequentially; $72 \% \mathrm{H}_{2} \mathrm{SO}_{4}$ was used for lignin quantification (Van Soest et al., 1991). Feed, orts, chromic oxide pellets, duodenal, and fecal samples were analyzed for total fatty acids by GLC (Sukhija and Palmquist, 1988). Chromic oxide pellets and duodenal and fecal samples were analyzed for Cr by atomic absorption spectroscopy (Williams et al., 1962). Duodenal samples were analyzed for $\mathrm{NH}_{3} \mathrm{~N}$ content (Bremner and Keeney, 1965) and total purine concentration (Zinn and Owens, 1986) as modified by Ushida et al. (1985) for use as a microbial flow marker. Neutral detergent insoluble N (NDIN) and ADIN concentrations of feed offered were determined by the NDF or 
ADF procedure described previously (without urea addition) followed by Kjeldahl $\mathrm{N}$ analysis.

Feed, orts, chromic oxide pellets, and duodenal and fecal samples were reground to pass through a 1-mm screen and analyzed for total NSC concentration by GLC (Callison et al., 2001). Area under the curve was used to calculate individual sugar concentrations, which were corrected for area of the myo-inositol internal standard. Individual sugar concentrations were summed to yield total hydrolyzed sugar content. Pure corn starch was used to check recovery, which averaged $103 \%(\mathrm{SD}=10)$.

Core samples of ruminal concentration (approximately $1000 \mathrm{ml}$ ) were taken on four consecutive days (d 14 through 17 ) at $3,6,9$, or $12 \mathrm{~h}$ after the a.m. feeding for harvesting and isolating particulate-associated bacteria by blending (Callison et al., 2001). The bacterial cells were lyophilized and analyzed for DM, OM, N, FA, and purines as described previously.

\section{Calculations}

The $\mathrm{NE}_{\mathrm{L}}$ concentration of the diet was calculated using the equation of Weiss (1993). The NFC concentration of the diet was determined by difference [OM $\mathrm{NDF}-\mathrm{CP}-(\mathrm{FA}+1)+(\mathrm{NDIN} * 6.25)]$. The NFC component of the TDN equation used to calculate $\mathrm{NE}_{\mathrm{L}}$ was adjusted for NSC digestibility in the SF diets. An adjustment factor for each SF diet (LSF and MSF) was calculated by dividing the apparent total tract NSC digestibility for the SF diet by the NSC digestibility for the FCG diet.

The average amount of $\mathrm{Cr}$ dosed daily was divided by the concentration of $\mathrm{Cr}$ in the duodenal and fecal samples to determine daily flow of DM to the duodenum and rectum. Digestibility coefficients were then calculated based on the intake (adjusted for orts) and the duodenal and fecal flows of each nutrient (OM, NDF, NSC, and N). Microbial N, OM, or NSC flows were calculated by multiplying the bacterial $\mathrm{N}$ :purine, OM:purine, or NSC:purine ratios by total purine flow at the duodenum. The NSC content of the bacterial sample was determined by difference $[\mathrm{NSC}=\mathrm{OM}-(\mathrm{N}$ * 6.25) - $(\mathrm{FA}+1)$ ]. True OM and NSC flows to the duodenum were corrected for bacterial contributions. Efficiency of microbial protein synthesis was expressed per unit of OM or unit of carbohydrate (NDF plus NSC) digestion on apparent and true bases.

\section{Statistical Analyses}

Data were analyzed using the MIXED procedure of SAS (1999) with the following model:

$$
\mathrm{Y}_{\mathrm{ijk}}=\mu+\mathrm{T}_{\mathrm{i}}+\mathrm{C}_{\mathrm{j}}+\mathrm{P}_{\mathrm{k}}+\mathrm{e}_{\mathrm{ijk}}
$$

where $\mu$ = overall population mean, $\mathrm{T}_{\mathrm{i}}=$ fixed effect of ith treatment, $C_{j}=$ random effect of $j$ th cow, $P_{k}=$ fixed effect of $k$ th period, and $e_{i j k}=$ residual error. Preplanned contrasts compared the linear, quadratic, and cubic effects of increasing WCS in the diet when G corn was used as the corn source (FCG, LG, MG, and HG). An additional contrast compared the effect of corn source (LG and MG vs. LSF and MSF). The final contrast evaluated the interaction of corn source and level of WCS for LG, MG, LSF, and MSF treatments. Significant differences were declared at $P<0.05$ unless otherwise stated. When the MIXED procedure would not converge for a few datasets (ruminal FA disappearance expressed as percentage of total FA intake, percentage of total $\mathrm{C}_{18}$ intake, and percentage of unsaturated FA intake), data were analyzed using Proc GLM (SAS, 1999). Individual $\mathrm{pH}, \mathrm{VFA}$, and $\mathrm{NH}_{3} \mathrm{~N}$ concentrations were analyzed over time using the repeated measures analysis of the MIXED procedure of SAS (1999). Cow was designated as the only random effect. First-order autoregressive [AR(1)] was used as the covariance structure for $\mathrm{pH}$, acetate:propionate, total VFA concentration, and most individual VFA concentrations. Heterogeneous compound symmetry (CSH) was used as the covariance structure for valerate. Heterogeneous firstorder autoregressive [ARH(1)] was used as the covariance structure for ruminal $\mathrm{NH}_{3} \mathrm{~N}$ concentration. When interactions for treatment $\times$ time were not deemed to be significant $(P \geq 0.10)$, averages over all times were reported.

\section{RESULTS AND DISCUSSION}

The chemical composition of the diets is shown in Table 2. Total NDF concentrations were higher than the formulated values of $28 \%$ for each diet due to variations in NDF in WCS and the grain mix. The FNDF concentration was determined and adjusted before each collection period. Cottonseed hulls were added to the diets in slightly different amounts during each period to balance NDF and enable the direct substitution of alfalfa silage NDF with cotton product (WCS plus linted cottonseed hulls) NDF on a one-to-one basis as alfalfa silage NDF varied. The ratio of WCS to cottonseed hulls was, on average, 10:1.

The NFC concentrations of the diets (Table 2) were similar to the values used in ration balancing. The enzymatic procedure used to determine NSC concentration was based on total hydrolyzed sugar concentrations. Several of the feeds used in this study (alfalfa silage, soybean meal, and soybean hulls) contain greater than $10 \%$ soluble fiber (Hall et al., 1997). The soluble fiber 
Table 2. Chemical composition of experimental diets.

\begin{tabular}{|c|c|c|c|c|c|c|}
\hline \multirow[b]{2}{*}{ Item } & \multicolumn{6}{|c|}{$\operatorname{Diets}^{1}$} \\
\hline & FCG & LG & MG & HG & LSF & MSF \\
\hline $\mathrm{DM}, \%$ & 58.4 & 61.3 & 64.3 & 67.9 & 62.0 & 64.0 \\
\hline NDF & 30.9 & 31.3 & 31.3 & 31.4 & 31.1 & 31.6 \\
\hline Forage NDF & 21.5 & 18.3 & 15.4 & 12.3 & 18.1 & 15.4 \\
\hline $\mathrm{ADF}$ & 21.5 & 21.4 & 21.7 & 21.5 & 21.6 & 21.8 \\
\hline $\mathrm{ADL}^{2}$ & 4.54 & 4.47 & 4.57 & 4.72 & 4.62 & 4.79 \\
\hline $\mathrm{CP}$ & 18.4 & 18.8 & 18.6 & 18.8 & 18.6 & 18.9 \\
\hline $\mathrm{NDIN}^{3}$ & 0.61 & 0.52 & 0.50 & 0.44 & 0.58 & 0.54 \\
\hline $\mathrm{ADIN}^{4}$ & 0.23 & 0.22 & 0.22 & 0.21 & 0.26 & 0.24 \\
\hline Ash & 7.67 & 7.50 & 7.13 & 6.71 & 7.49 & 7.28 \\
\hline Fatty acids & 4.39 & 4.57 & 4.68 & 4.97 & 4.33 & 4.44 \\
\hline $\mathrm{NFC}^{5}$ & 42.0 & 40.6 & 40.8 & 40.3 & 41.7 & 40.7 \\
\hline $\mathrm{NSC}^{6}$ & 22.8 & 26.3 & 25.9 & 28.9 & 25.8 & 24.9 \\
\hline $\mathrm{TDN}^{7}$ & 68.3 & 70.1 & 70.6 & 68.7 & 70.2 & 70.8 \\
\hline $\mathrm{NE}_{\mathrm{L}}, \mathrm{Mcal} / \mathrm{kg}$ of $\mathrm{DMI}^{7}$ & 1.69 & 1.69 & 1.70 & 1.72 & 1.72 & 1.73 \\
\hline
\end{tabular}

${ }^{1} \mathrm{FCG}=$ Forage control with ground corn; $\mathrm{LG}=$ low cottonseed with ground corn; $\mathrm{MG}=$ medium cottonseed with ground corn; HG = high cottonseed with ground corn; LSF = low cottonseed with steam-flaked corn, and $\mathrm{MSF}=$ medium cottonseed with steam-flaked corn.

${ }^{2} \mathrm{ADL}=$ Acid detergent lignin.

${ }^{3}$ NDIN $=$ Neutral detergent insoluble nitrogen.

${ }^{4} \mathrm{ADIN}=$ Acid detergent insoluble nitrogen.

${ }^{5} \mathrm{NFC}=$ Nonfiber carbohydrates $[\mathrm{OM}-\mathrm{NDF}-\mathrm{CP}-(\mathrm{FA}+1)+(\mathrm{NDIN} * 6.25)]$.

${ }^{6} \mathrm{NSC}=$ Nonstructural carbohydrates; analyzed by enzymatic determination.

${ }^{7}$ Calculated using the equation from Weiss et al. (1993); corrected for total tract starch digestibility of diets containing steam-flaked corn (LSF and MSF) relative to FCG.

would be included in NFC, but not NSC, explaining the difference between values for NFC and NSC.

St-Pierre and Jones (1999) suggested that, if the interest of a researcher is to use a given set of research animals to make inferences to a larger population, the effect of cow should be considered random. On this basis, data were analyzed using the MIXED procedure of SAS (1999) with cow as a random effect. The SE for data presented in this paper using Proc MIXED are approximately 15 to $25 \%$ larger than those obtained using GLM because the MIXED model considers the variance of cow in addition to the residual variance. However, the choice of procedure (MIXED vs. GLM) had little effect on the significance of the contrasts.

As the proportion of dietary WCS increased, OM intake increased quadratically (Table 3). Ruminal and total tract OM digestibilities were not affected by level of WCS substitution, despite a linear increase in apparent ruminal NSC digestibility. However, when duodenal flows were adjusted to account for bacterial NSC flows, true ruminal NSC digestibility did not differ. Additionally, WCS addition did not affect total tract NSC digestibility considerably, although there was a quadratic trend.

Steam-flaking decreased OM intake but increased true ruminal $\mathrm{OM}$ digestibility compared with grinding (Table 3). No differences were observed for apparent total tract OM digestibility between corn sources. Compensatory postruminal digestion of starch or NDF tended to minimize differences in apparent total tract OM digestibility among grain processing methods (Firkins et al., 2001).

Apparent and true ruminal NSC digestibilities were higher for SF corn diets compared with $\mathrm{G}$ corn diets (77.6 and $96.1 \%$ for SF vs. 55.1 and 70.7 for G, respectively). Apparent ruminal NSC digestibilities were substantially lower than true ruminal NSC digestibilities (average measured values of $21 \% \mathrm{NSC}$ in bacteria). Despite compensatory intestinal NSC digestibility in G corn diets, total tract NSC digestibility was slightly lower for G than SF corn. Callison et al. (2001) observed slightly higher apparent ruminal and total tract NSC digestibilities (70.1 and $98.0 \%$, respectively) when finely ground corn of similar particle size $(1.15 \mathrm{~mm})$ was fed. Approximately $96 \%$ of the NSC in SF corn was truly digested in the rumen; consequently, appararent total tract NSC digestibility for SF corn (99.4 and 99.8\% for LSF and MSF, respectively) was slightly higher than the average of $94.2 \%$ reported by Firkins et al. (2001). This may be a result of our NSC procedure or attributed to the density of the SF corn used in the current study ( 0.360 to $0.386 \mathrm{~kg} / \mathrm{L}$ ), which should be optimal (Theurer et al., 1999). 
Table 3. Least squares means for OM, NSC, ${ }^{1}$ and NDF digestibilities by cows fed diets in which whole cottonseed replaced alfalfa silage and was fed with ground or steam-flaked corn.

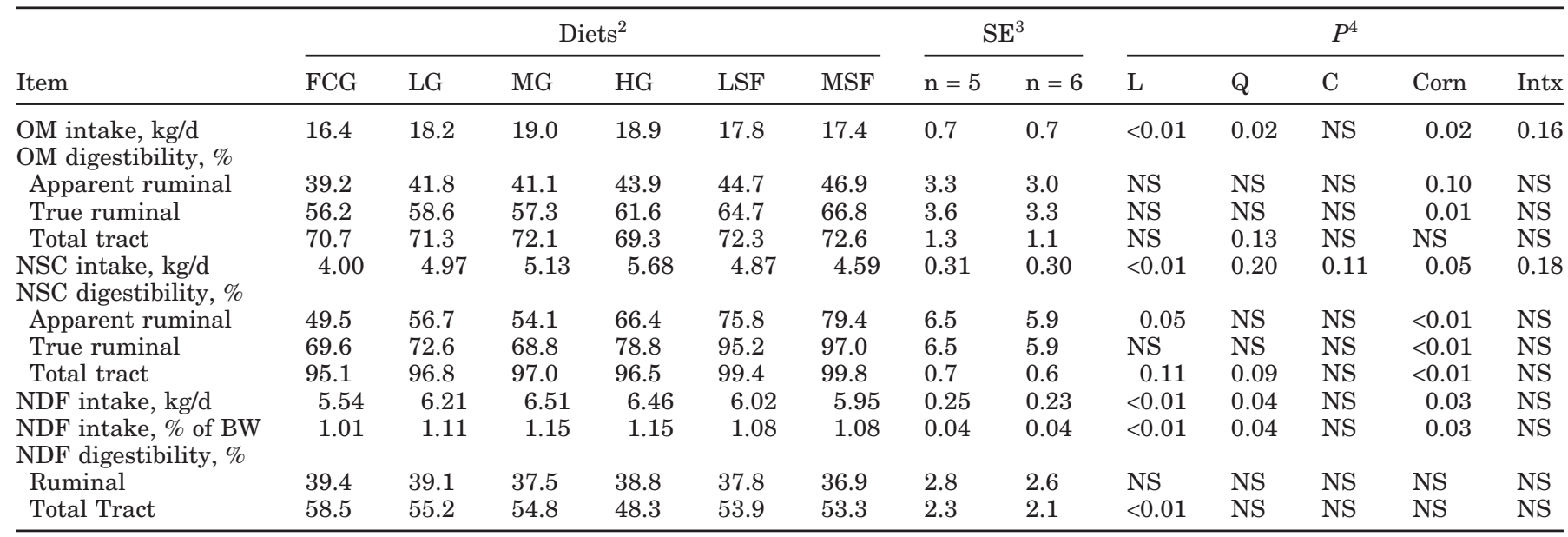

${ }^{1}$ Nonstructural carbohydrates analyzed by enzymatic determination.

${ }^{2} \mathrm{FCG}=$ Forage control with ground corn; $\mathrm{LG}=$ low cottonseed with ground corn; $\mathrm{MG}=$ medium cottonseed with ground corn; HG = high cottonseed with ground corn; LSF = low cottonseed with steam-flaked corn, and MSF = medium cottonseed with steam-flaked corn.

${ }^{3}$ For the LG treatment $\mathrm{n}=5$; for all other treatments $\mathrm{n}=6$.

${ }^{4}$ Probability of a treatment response; NS $=$ not significant $(P>0.20)$. Contrasts compared the linear $(\mathrm{L})$, quadratic $(\mathrm{Q})$, and cubic $(\mathrm{C})$ effects of increasing level of whole cottonseed in the diet when ground corn was used as the corn source (FCG, LG, MG and HG). Contrast Corn compared the effect of corn source (ground vs. steam-flaked) when low or medium levels of cottonseed were fed (LG and MG vs. LSF and MSF). Contrast Intx evaluated the interaction of corn source (ground or steam-flaked) and level of cottonseed (low or medium) in LG, MG, LSF, and MSF treatments.

Intake of NDF increased quadratically as the proportion of WCS in the diet increased (Table 3). Because the NDF concentration of the diets was similar (Table 2 ), this response was a result of increased DMI. There was no effect of level of WCS substitution on ruminal NDF digestibility (Table 3). During diet formulation, the estimated FA concentration from oilseeds was limited to approximately $3 \%$ of dietary DM (Table 1) to prevent depression in ruminal fiber digestion (Jenkins, 1994; Palmquist, 1995).

The amount of postruminal NDF digestion decreased as the concentration of WCS increased (Table 3), suggesting that NDF from WCS was not as digestible in the large intestine as was NDF from alfalfa silage. Cottonseed hulls contained more digestible NDF (54.2\% of original NDF) compared with alfalfa (41.3\% of original $\mathrm{NDF}$ ), but ground alfalfa had a higher rate of digestion $\left(0.0547 \mathrm{~h}^{-1}\right)$ than ground cottonseed hulls $\left(0.0208 \mathrm{~h}^{-1}\right)$ in vitro (Bhatti and Firkins, 1995). A lower digestion rate and higher proportion of digestible NDF from WCS should promote passage and compensatory digestion of WCS NDF in the large intestine. However, the opposite effect occurred in our study, apparently because of increased negative associative effects as forage decreased (Firkins, 1997).

Corn processing decreased NDF intake because of reduced OM intake but did not affect NDF digestibility (Table 3 ). The effects of corn processing on NDF digest- ibility have been variable; increasing ruminal starch availability has decreased (Poore et al., 1993a; Plascencia and Zinn, 1996; Joy et al., 1997), increased (Chen et al., 1994), or had no effect (Poore et al., 1993b; Knowlton et al., 1998) on NDF digestibility.

As the level of WCS substitution increased, the average ruminal $\mathrm{pH}$ decreased linearly from 6.28 for cows fed the FCG diet to 5.93 for cows fed the HG diet (Table 4). The decreased $\mathrm{pH}$ could be a result of increased $\mathrm{OM}$ and NSC intakes increasing ruminally fermentable substrate, decreasing salivary buffer secretion, or to decreased cation exchange capacity as alfalfa silage decreased. Because total chewing time was not affected by treatment (Harvatine et al., 2002) and cottonseed meal had a similar cation exchange capacity as alfalfa (Van Soest et al., 1991), the former reason seems more likely. The lack of $\mathrm{pH}$ effect for corn source explains why ruminal NDF digestibility was not decreased when SF corn replaced G corn.

Although there were no differences among diets in total VFA concentration, the acetate:propionate ratio decreased linearly with increasing level of WCS substitution (Table 4). Change in acetate:propionate is a reflection of the linear increase in propionate concentration and the linear decrease in acetate concentration with increasing level of WCS. Ruminal VFA concentrations responded in a similar manner when NDF from WCS replaced FNDF (Clark and Armentano, 1993). 
Table 4. Least squares means for ruminal fluid characteristics of cows fed diets in which whole cottonseed replaced alfalfa silage and was fed with ground or steam-flaked corn.

\begin{tabular}{|c|c|c|c|c|c|c|c|c|c|c|c|c|c|}
\hline \multirow[b]{2}{*}{ Item } & \multicolumn{6}{|c|}{$\operatorname{Diets}^{1}$} & \multicolumn{2}{|c|}{$\mathrm{SE}^{2}$} & \multicolumn{5}{|c|}{$P^{3}$} \\
\hline & FCG & LG & MG & $\mathrm{HG}$ & LSF & MSF & $\mathrm{n}=5$ & $\mathrm{n}=6$ & $\mathrm{~L}$ & Q & $\mathrm{C}$ & Corn & Intx \\
\hline Ruminal pH & 6.28 & 6.13 & 6.12 & 5.93 & 6.07 & 6.02 & 0.08 & 0.07 & $<0.01$ & NS & NS & NS & NS \\
\hline Acetate & 67.7 & 66.4 & 65.0 & 63.9 & 63.8 & 61.9 & 1.01 & 0.98 & $<0.01$ & NS & NS & $<0.01$ & NS \\
\hline Propionate & 17.5 & 18.7 & 20.7 & 21.9 & 21.6 & 23.3 & 1.26 & 1.23 & $<0.01$ & NS & NS & $<0.01$ & NS \\
\hline Butyrate & 11.1 & 11.2 & 10.5 & 10.6 & 11.2 & 11.3 & 0.53 & 0.48 & 0.18 & NS & NS & NS & NS \\
\hline Isobutyrate & 0.88 & 0.90 & 0.89 & 0.85 & 0.76 & 0.73 & 0.05 & 0.05 & NS & 0.16 & NS & $<0.01$ & NS \\
\hline Acetate:propionate & 3.98 & 3.59 & 3.21 & 3.01 & 2.98 & 2.77 & 0.22 & 0.21 & $<0.01$ & NS & NS & $<0.01$ & NS \\
\hline $\mathrm{NH}_{3} \mathrm{~N}, \mathrm{mg} / \mathrm{dl}$ & 10.28 & 12.41 & 15.22 & 17.62 & 8.35 & 9.70 & 1.29 & 1.24 & $<0.01$ & NS & NS & $<0.01$ & NS \\
\hline
\end{tabular}

${ }^{1} \mathrm{FCG}=$ Forage control with ground corn; $\mathrm{LG}=$ low cottonseed with ground corn; $\mathrm{MG}=$ medium cottonseed with ground corn; HG = high cottonseed with ground corn; LSF = low cottonseed with steam-flaked corn, and MSF = medium cottonseed with steam-flaked corn.

${ }^{2}$ For the LG treatment $\mathrm{n}=5$; for all other treatments $\mathrm{n}=6$.

${ }^{3}$ Probability of a treatment response; NS = not significant $(P>0.20)$. Contrasts compared the linear $(\mathrm{L})$, quadratic $(\mathrm{Q})$, and cubic $(\mathrm{C})$ effects of increasing level of whole cottonseed in the diet when ground corn was used as the corn source (FCG, LG, MG, and HG). Contrast Corn compared the effect of corn source (ground vs. steam-flaked) when low or medium levels of cottonseed were fed (LG and MG vs. LSF and MSF). Contrast Intx evaluated the interaction of corn source (ground or steam-flaked) and level of cottonseed (low or medium) in LG, MG, LSF, and MSF treatments.

Cows fed the diets with G corn had a higher acetate:propionate than did cows fed the diets with SF corn, resulting from a decrease in acetate concentration and an increase in propionate concentration. Other researchers have observed a decrease in acetate:propionate and an increase in propionate concentration when rapidly degradable NSC was fed (Ekinci and Broderick, 1997; Joy et al., 1997; Dann et al., 1999). When SF corn replaced G corn, there was an increase in concentration of valerate and a decrease in concentrations of isovalerate and isobutyrate (Table 4). Additionally, there was an interaction between corn source and level of WCS for valerate and isovalerate concentrations. An explanation for these observations is not clear.

Ruminal $\mathrm{NH}_{3} \mathrm{~N}$ concentrations have been used as a measure of the ruminal availability of $\mathrm{N}$ and the efficiency of protein utilization in the rumen. Ruminal $\mathrm{NH}_{3} \mathrm{~N}$ concentrations in the current study (Table 4) all were above the minimum concentration of 6.2 to 8.0 $\mathrm{mg} / \mathrm{dl}$ suggested to maintain NDF digestion (Hoover, 1986). The diets were balanced to contain higher RDP than required (Table 1).

As expected from the linear increase in ruminal $\mathrm{NH}_{3} \mathrm{~N}$ concentration (Table 4), the duodenal flow of $\mathrm{NH}_{3} \mathrm{~N}$ increased linearly (Table 5) as WCS addition increased. However, nonmicrobial nonammonia $\mathrm{N}$ flow (\% of $\mathrm{N}$ intake) decreased linearly with increasing WCS addition (Table 5). Diets were balanced to be equivalent in estimated RDP ( $64 \%$ of $\mathrm{CP}$ and $12 \%$ of DM). As NDF from WCS replaced FNDF, the concentration of roasted soybeans was reduced to maintain similar FA concentrations from oilseeds (roasted soybeans plus WCS) (Ta- ble 1). The RDP concentration of WCS (43.0\% of CP) from Spartan Ration Evaluator (VandeHaar et al., 1992), which was used in diet formulation, was higher than that previously reported $(30.4 \%$ of $\mathrm{CP}$ ) for raw WCS (Pires et al., 1997). As a result, nonmicrobial nonammonia N (\% of intake) ranged from $45.7 \%$ for FCG to $30.0 \%$ for $\mathrm{HG}$ (Table 5). Total tract $\mathrm{N}$ digestibility increased linearly with increasing WCS, which also indicates that heating of roasted soybeans might have been greater than planned.

Flow of microbial $\mathrm{N}$ to the duodenum increased linearly with WCS addition (Table 5), probably because OM intake increased (Table 3). However, the efficiency of microbial $\mathrm{N}$ synthesis (calculated per unit of carbohydrate degraded) decreased linearly as WCS addition increased (Table 5). Because branched-chain VFA concentrations (Table 4) did not differ across treatments and $\mathrm{NH}_{3} \mathrm{~N}$ concentrations should have been adequate, RDP did not appear to limit microbial growth. Therefore, the difference in microbial $\mathrm{N}$ synthesis appears to be related to ruminal $\mathrm{pH}$. As ruminal $\mathrm{pH}$ decreased linearly (Table 4), the efficiency of microbial $\mathrm{N}$ synthesis per unit of carbohydrate digested also decreased linearly (Table 5). Russell (1998) suggested that, when excess carbohydrates are available in the rumen, microorganisms expend extra nongrowth energy in a process termed energy spilling. Although not measured in this study, increased lactate concentration might have contributed to observed $\mathrm{pH}$ differences as WCS increased. Additionally, the decreased efficiency of microbial protein synthesis could potentially be a result of the linear decrease in the passage rate of potentially digestible 
Table 5. Least squares means for $\mathrm{N}$ digestibility and efficiency of bacterial growth by cows fed diets in which whole cottonseed replaced alfalfa silage and was fed with ground or steam-flaked corn.

\begin{tabular}{|c|c|c|c|c|c|c|c|c|c|c|c|c|c|}
\hline Item $^{4}$ & \multicolumn{6}{|c|}{ Diets $^{1}$} & \multicolumn{2}{|c|}{$\mathrm{SE}^{2}$} & \multicolumn{5}{|c|}{$P^{3}$} \\
\hline $\begin{array}{l}\mathrm{N} \text { intake, g/d } \\
\text { Duodenal flow, g/d }\end{array}$ & 521 & 595 & 608 & 607 & 570 & 568 & 26 & 25 & $<0.01$ & 0.03 & NS & 0.06 & NS \\
\hline Ammonia $\mathrm{N}$ & 11.5 & 14.3 & 15.1 & 18.2 & 10.7 & 12.3 & 1.4 & 1.2 & $<0.01$ & NS & NS & 0.01 & NS \\
\hline Microbial N & 247 & 267 & 271 & 295 & 319 & 301 & 16 & 15 & 0.01 & NS & NS & $<0.01$ & NS \\
\hline Nonmicrobial NAN & 234 & 227 & 212 & 182 & 197 & 164 & 31 & 28 & 0.14 & NS & NS & 0.14 & NS \\
\hline $\begin{array}{l}\text { Nonmicrobial NAN, \% of } \mathrm{N} \text { intake } \\
\text { Efficiency of microbial } \mathrm{N} \text { synthesis }\end{array}$ & 45.7 & 36.9 & 34.3 & 30.0 & 34.5 & 28.6 & 4.5 & 4.0 & 0.01 & NS & NS & NS & NS \\
\hline $\mathrm{g} \mathrm{N} / \mathrm{kg}$ OM truly digested & 27.6 & 25.4 & 25.6 & 25.6 & 27.5 & 25.7 & 1.7 & 1.5 & NS & NS & NS & NS & NS \\
\hline Efficiency of microbial $\mathrm{N}$ synthesis & & & & & & & & & & & & & \\
\hline g N/ kg CHO apparently digested & 78.4 & 57.4 & 59.4 & 48.6 & 55.3 & 53.8 & 10.5 & 9.5 & 0.04 & NS & NS & NS & NS \\
\hline g N/ kg CHO truly digested & 57.8 & 47.5 & 49.8 & 43.4 & 46.9 & 46.2 & 5.4 & 4.9 & 0.05 & NS & NS & NS & NS \\
\hline $\begin{array}{l}\text { Apparent total tract } \mathrm{N} \text { digestibility, } \\
\% \text { of intake }\end{array}$ & 62.5 & 66.5 & 68.6 & 69.9 & 66.0 & 69.6 & 1.1 & 1.0 & $<0.01$ & 0.20 & NS & NS & NS \\
\hline
\end{tabular}

${ }^{1} \mathrm{FCG}=$ forage control with ground corn $\mathrm{LG}=$ low cottonseed with ground corn; $\mathrm{MG}=$ medium cottonseed with ground corn; $\mathrm{HG}=$ high cottonseed with ground corn; LSF = low cottonseed with steam-flaked corn, and MSF = medium cottonseed with steam-flaked corn.

${ }^{2}$ For the LG treatment $\mathrm{n}=5$; for all other treatments $\mathrm{n}=6$.

${ }^{3}$ Probability of a treatment response; NS $=$ not significant $(P>0.20)$. Contrasts compared the linear $(\mathrm{L})$, quadratic $(\mathrm{Q})$, and cubic $(\mathrm{C})$ effects of increasing level of whole cottonseed in the diet when ground corn was used as the corn source (FCG, LG, MG, and HG). Contrast Corn compared the effect of corn source (ground vs. steam-flaked) when low or medium levels of cottonseed were fed (LG and MG vs. LSF and MSF). Contrast Intx evaluated the interaction of corn source (ground or steam-flaked) and level of cottonseed (low or medium) in LG, MG, LSF, and MSF treatments.

${ }^{4} \mathrm{NAN}=$ Nonammonia $\mathrm{N} ; \mathrm{CHO}=$ carbohydrate $(\mathrm{NDF}+$ non-structural carbohydrate $)$.

NDF (Harvatine et al., 2001). Because of the extensive attachment of ruminal microbes to feed particles, Firkins (1996) explained that a slower particulate passage rate could increase the proportion of energy spent on cell maintenance.

Substituting SF corn for G corn decreased ruminal $\mathrm{NH}_{3} \mathrm{~N}$ concentration (Table 4) and duodenal flow of $\mathrm{NH}_{3} \mathrm{~N}$ (Table 5). Additionally, duodenal flow of microbial $\mathrm{N}$ increased by about $15 \%$ with the use of SF corn. In a recent review, Firkins et al. (2001) determined that microbial $\mathrm{N}$ flow to the duodenum was greater for cows fed SF compared with dry-rolled or G corn. Ruminally fermentable NSC intake (NSC intake $\times$ true ruminal NSC digestibility) increased by over $1 \mathrm{~kg} / \mathrm{d}$ when SF corn was fed (data not shown; see Table 3), which provided more substrate for microbial growth. Increased NSC availability combined with a lack of $\mathrm{pH}$ differences (Table 4), probably increased $\mathrm{NH}_{3} \mathrm{~N}$ utilization by ruminal microorganisms. As a result, method of corn processing did not affect efficiency of microbial protein synthesis.

Intakes of total $\mathrm{FA}, \mathrm{C}_{16}, \mathrm{C}_{18: 1}$, and $\mathrm{C}_{18: 2}$ increased linearly and $\mathrm{C}_{18: 3}$ intake decreased quadratically with increasing WCS addition (Table 6). Although diets were balanced to contain equivalent crude fat concentrations, the FA concentration of the diet increased from 4.39 to $4.97 \%$ with increasing WCS inclusion (Table 2). Alfalfa silage has fewer lipids in the form of FA than WCS (Van Soest, 1994). By design, as the dietary pro- portion of WCS increased, the proportion of alfalfa silage and whole roasted soybeans decreased (Table 1). Typical alfalfa silage contains $39.0 \% \mathrm{C}_{18: 3}$ (as a percentage of total FA), whereas soybeans and WCS contain $6.8 \%$ and less than $0.5 \%$, respectively (Van Soest, 1994). Additionally, WCS contain $25.3 \% \mathrm{C}_{16}$ (as a percentage of total FA), but soybeans contain $10.7 \% \mathrm{C}_{16}$, explaining the linear increase in $\mathrm{C}_{16}$ intake as WCS increased and roasted soybeans decreased.

There were negative FA disappearances for total FA and total $\mathrm{C}_{18} \mathrm{FA}$ for FCG (Table 6). In past trials, an average of $87 \%$ of dietary FA was recovered at the duodenum; however, de novo FA synthesis by ruminal microbes can result in a net gain of FA across the rumen (Jenkins, 1994). Thus, it is likely that de novo FA synthesis contributed to the increase in FA flow at the duodenum for cows fed FCG. There were linear increases in ruminal disappearance of total $\mathrm{FA}$, total $\mathrm{C}_{18}$ FA, and unsaturated FA with increasing WCS addition (Table 6). To our knowledge, the ruminal disappearance of FA from WCS has not been compared with that of roasted soybeans in a single trial. Palmquist (1995) noted that the in situ disappearance of FA was higher for whole roasted soybeans (36.6\%) compared with WCS $(-5.86 \%)$. He attributed differences in FA disappearance to the physical structure of the oilseed; the hull of the soybean is more digestible than the hull of WCS, so the digestion and utilization of WCS might be more dependent on rumination and mastication to provide 
Table 6. Least squares means for fatty acid (FA) digestibility by cows fed diets in which whole cottonseed replaced alfalfa silage and was fed with ground or steam-flaked corn.

\begin{tabular}{|c|c|c|c|c|c|c|c|c|c|c|c|c|c|}
\hline \multirow[b]{2}{*}{ Item } & \multicolumn{6}{|c|}{$\operatorname{Diets}^{1}$} & \multicolumn{2}{|c|}{$\mathrm{SE}^{2}$} & \multicolumn{5}{|c|}{$P^{3}$} \\
\hline & FCG & LG & $\mathrm{MG}$ & HG & LSF & MSF & $\mathrm{n}=5$ & $\mathrm{n}=6$ & $\mathrm{~L}$ & $\mathrm{Q}$ & $\mathrm{C}$ & Corn & Intx \\
\hline \multicolumn{14}{|l|}{ FA intake, g/d } \\
\hline Total FA & 770 & 890 & 946 & 1008 & 825 & 826 & 49 & 45 & $<0.01$ & NS & NS & 0.01 & NS \\
\hline Total $\mathrm{C}_{16}$ & 111 & 145 & 184 & 224 & 141 & 167 & 8 & 8 & $<0.01$ & NS & NS & 0.08 & NS \\
\hline Total $\mathrm{C}_{18}$ & 578 & 665 & 686 & 717 & 607 & 588 & 38 & 35 & $<0.01$ & NS & NS & $<0.01$ & NS \\
\hline $\mathrm{C}_{18.0}$ & 26.3 & 28.5 & 26.9 & 26.3 & 27.6 & 25.0 & 1.6 & 1.5 & NS & NS & NS & NS & NS \\
\hline $\mathrm{C}_{18: 1}$ & 123 & 148 & 152 & 162 & 128 & 124 & 9.2 & 8.5 & $<0.01$ & NS & NS & $<0.01$ & NS \\
\hline $\mathrm{C}_{18: 2}$ & 331 & 402 & 436 & 480 & 365 & 375 & 24 & 22 & $<0.01$ & NS & NS & 0.01 & NS \\
\hline $\mathrm{C}_{18: 3}$ & 97.4 & 86.8 & 70.3 & 48.3 & 86.0 & 63.9 & 3.9 & 3.6 & $<0.01$ & 0.04 & NS & 0.18 & NS \\
\hline \multicolumn{14}{|l|}{ FA flow to the duodenum, $\mathrm{g} / \mathrm{d}$} \\
\hline Total FA & 806 & 874 & 893 & 926 & 776 & 749 & 41 & 38 & $<0.01$ & NS & NS & $<0.01$ & NS \\
\hline Total $\mathrm{C}_{16}$ & 133 & 157 & 174 & 197 & 142 & 148 & 9 & 8 & $<0.01$ & NS & NS & $<0.01$ & NS \\
\hline Total $\mathrm{C}_{18}$ & 610 & 657 & 664 & 682 & 576 & 549 & 30 & 28 & 0.03 & NS & NS & $<0.01$ & NS \\
\hline $\mathrm{C}_{18: 0}$ & 352 & 417 & 439 & 481 & 358 & 349 & 20 & 19 & $<0.01$ & NS & NS & $<0.01$ & NS \\
\hline Total $\mathrm{C}_{18: 1}$ & 142 & 139 & 138 & 135 & 129 & 127 & 11 & 10 & NS & NS & NS & 0.19 & NS \\
\hline trans $\mathrm{C}_{18: 1}$ & 32.1 & 32.9 & 42.1 & 41.7 & 31.1 & 38.7 & 4.5 & 3.9 & 0.04 & NS & NS & NS & NS \\
\hline $\mathrm{C}_{18: 2}$ & 101 & 86 & 76 & 57 & 76 & 63 & 11 & 10 & $<0.01$ & NS & NS & 0.19 & NS \\
\hline $\mathrm{C}_{18: 3}^{10.2}$ & 15.8 & 13.0 & 11.0 & 7.6 & 12.6 & 10.6 & 1.2 & 1.1 & $<0.01$ & NS & NS & NS & NS \\
\hline \multicolumn{14}{|l|}{ Ruminal FA disappearance } \\
\hline Total FA, \% of intake & -8.0 & 1.9 & 5.4 & 8.4 & 6.0 & 9.2 & 4.8 & 4.2 & 0.01 & NS & NS & NS & NS \\
\hline Total $\mathrm{C}_{18} \mathrm{FA}, \%$ of intake & -9.5 & 1.3 & 2.8 & 5.2 & 4.7 & 6.6 & 5.6 & 4.9 & 0.05 & NS & NS & NS & NS \\
\hline Unsaturated $\mathrm{C}_{18} \mathrm{FA}, \%$ of intake & 51.7 & 62.5 & 66.1 & 70.9 & 62.6 & 64.4 & 2.9 & 2.5 & $<0.01$ & NS & NS & NS & NS \\
\hline \multicolumn{14}{|l|}{ Apparent total tract FA digestibility, } \\
\hline Biohydrogenation ${ }^{4}$ & 56.1 & 61.9 & 64.0 & 67.1 & 56.9 & 56.6 & $\begin{array}{l}2.0 \\
3.8\end{array}$ & $\begin{array}{l}2.5 \\
3.5\end{array}$ & 0.01 & NS & NS & 0.05 & NS \\
\hline Biohydrogenation $^{5}$ & 65.9 & 70.8 & 72.5 & 75.6 & 67.1 & 67.5 & 3.2 & 2.9 & $<0.01$ & NS & NS & 0.10 & NS \\
\hline
\end{tabular}

${ }^{1} \mathrm{FCG}=$ Forage control with ground corn; $\mathrm{LG}=$ low cottonseed with ground corn; $\mathrm{MG}=$ medium cottonseed with ground corn; HG = high cottonseed with ground corn; LSF = low cottonseed with steam-flaked corn, and MSF = medium cottonseed with steam-flaked corn.

${ }^{2}$ For the LG treatment $\mathrm{n}=5$; for all other treatments $\mathrm{n}=6$.

${ }^{3}$ Probability of a treatment response; NS = not significant $(P>0.20)$. Contrasts compared the linear $(\mathrm{L})$, quadratic $(\mathrm{Q})$, and cubic $(\mathrm{C})$ effects of increasing level of whole cottonseed in the diet when ground corn was used as the corn source (FCG, LG, MG, and HG). Contrast Corn compared the effect of corn source (ground vs. steam-flaked) when low or medium levels of cottonseed were fed (LG and MG vs. LSF and MSF). Contrast Intx evaluated the interaction of corn source (ground or steam-flaked) and level of cottonseed (low or medium) in LG, MG, LSF, and MSF treatments.(P - 0.10)D Slightly lower, biohydrogenation for SF than G corn was likely result of lower FA concentration (Table 2).

${ }^{4}$ Equation from Wu et al. (1991).

${ }^{5}$ Equation 2 from Tice et al. (1994).

microbial access to seed contents (Coppock et al., 1985). When WCS was replaced with a combination of whole raw soybeans and soybean hulls on a FA and NDF basis, the diet with WCS stimulated more chewing and ruminating activity than the diet containing soybean products (Abel-Caines et al., 1997). In our study, total tract FA digestibility tended to increase linearly with increasing WCS use, apparently because of increased availability of FA from WCS compared with that from roasted soybeans.

Biohydrogenation of $\mathrm{C}_{18} \mathrm{FA}$ and duodenal flow of trans $\mathrm{C}_{18: 1}$ increased linearly with increasing inclusion of WCS (Table 6), despite $\mathrm{pH}$ decreasing linearly to 5.93 (Table 4). Kalscheur et al. (1997) suggested that decreased ruminal $\mathrm{pH}$ interfered with complete biohydrogenation. When the effects of $\mathrm{pH}$ on lipolysis and biohydrogenation were compared in vitro, lipolysis and biohydrogenation were not significantly inhibited until pH declined below 6.0 (Van Nevel and Demeyer, 1996).
As WCS replaced alfalfa silage and roasted soybeans, the proportion of $\mathrm{C}_{18: 2}$ increased from 43.0 to $47.6 \%$ and $\mathrm{C}_{18: 3}$ decreased from 12.6 to $4.8 \%$ of total FA (data not shown). The $\mathrm{C}_{18: 3}$ is probably primarily from alfalfa in the form of glycolipids. Anaerovibrio lipolytica, a prominent lipolytic bacterium, is apparently incapable of hydrolyzing glycolipids such as galactolipids (Harfoot and Hazlewood, 1988) because the sugar group needs to be removed before lipolysis. Therefore, although these lipids are rapidly hydrolyzed, lipolysis might have been more rate limiting as a higher proportion of lipids were from alfalfa silage.

Dry matter intake increased quadratically as the proportion of WCS in the diet increased (Table 7), explaining similar responses in intakes of OM, NSC, and NDF (Table 3); N (Table 5); and FA (Table 6). Although with fewer treatments to detect a nonlinear response, substituting WCS for forage typically increases DMI (Clark and Armentano, 1997; Mooney and Allen, 1997; 
Table 7. Least squares means for lactation performance by cows fed diets in which whole cottonseed replaced alfalfa silage and was fed with ground or steam-flaked corn.

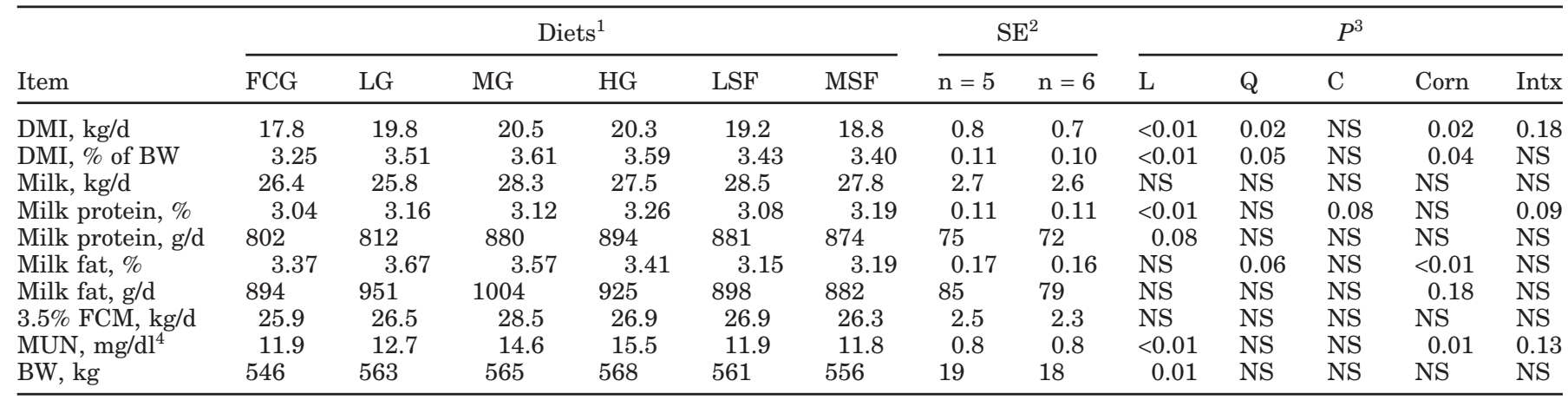

${ }^{1} \mathrm{FCG}=$ Forage control with ground corn; $\mathrm{LG}=$ low cottonseed with ground corn; $\mathrm{MG}=$ medium cottonseed with ground corn; $\mathrm{HG}=$ high cottonseed with ground corn; LSF = low cottonseed with steam-flaked corn, and MSF = medium cottonseed with steam-flaked corn.

${ }^{2}$ For the LG treatment $\mathrm{n}=5$; for all other treatments $\mathrm{n}=6$.

${ }^{3}$ Probability of a treatment response; NS $=$ not significant $(P>0.20)$. Contrasts compared the linear $(\mathrm{L})$, quadratic $(\mathrm{Q})$, and cubic $(\mathrm{C})$ effects of increasing level of whole cottonseed in the diet when ground corn was used as the corn source (FCG, LG, MG, and HG). Contrast Corn compared the effect of corn source (ground vs. steam-flaked) when low or medium levels of cottonseed were fed (LG and MG vs. LSF and MSF). Contrast Intx evaluated the interaction of corn source (ground or steam-flaked) and level of cottonseed (low or medium) in LG, MG, LSF, and MSF treatments.

${ }^{4}$ Milk urea nitrogen.

Slater et al., 2000). Lower fill should increase DMI in the short term (Allen, 2000), but increased ruminal carbohydrate availability could decrease DMI in the long term if acidosis or other metabolic disturbances develop.

When SF corn replaced G corn, DMI decreased. Although Yu et al. (1998) observed an increase in DMI when SF corn was compared to finely ground corn, most researchers reported no difference in DMI between cows fed dry-rolled or SF corn (Dann et al., 1999; Theurer et al., 1999). In practice, rations with high concentrations of ruminally degradable NSC, such as in the SF corn diets (LSF and MSF), would not likely be used because SF corn and dietary NFC concentrations would probably be lower than in our trial. The LSF and MSF diets had lower concentrations of forage than most of the studies comparing SF to G corn, perhaps explaining the impact of chemostatic regulation of DMI in the current study(Allen, 2000).

No differences were observed for yields of milk, milk fat, or $3.5 \%$ FCM (Table 7). There was a trend ( $P=$ $0.06)$ for a quadratic response for milk fat percentage with increasing substitution of forage with WCS (Table 7), with milk fat percentage being higher for the LG and MG diets. Milk fat percentage was not decreased despite the lower ruminal $\mathrm{pH}$, which has been associated with milk fat depression (Allen, 1997). Milk fat percentages were also not highly related to trans $\mathrm{C}_{18: 1}$. Although this lack of effect does not seem to coincide with current theory (Kalscheur et al., 1997), our fatty acid procedure could not separate various trans $\mathrm{C}_{18: 1}$ isomers, which has recently been documented to be crit- ical (Griinari et al., 2000). In two previous studies, replacing alfalfa silage NDF with NDF from WCS did not affect milk fat percentage (Clark and Armentano, 1993; Mooney and Allen, 1997) but increased (Clark and Armentano, 1993) or did not affect (Mooney and Allen, 1997) fat yield. However, replacing forage and concentrate with a combination of soybean hulls and WCS in $9.4 \%$ FNDF diets decreased milk fat percentage in another study (Slater et al., 2000). The ability to maintain milk fat percentage in this study supports the calculated 0.84 physical effectiveness factor for cottonseed NDF (Harvatine et al., 2002).

Milk protein percentage increased linearly and protein yield tended $(P<0.08)$ to increase with increasing WCS substitution (Table 7). Replacing FNDF with NDF from WCS increased milk protein percentage in one study (Clark and Armentano, 1993) but had no effect in another (Mooney and Allen, 1997). The increased supply of microbial protein $\mathrm{N}$ was offset by decreased nonmicrobial nonammonia N as WCS increased (Table 5), so increased intake of digestible $\mathrm{OM}$ and increased propionate concentration could have spared amino acids for milk protein synthesis (Theurer et al., 1999).

Processing method did not affect milk yield or milk protein (yield or percentage) in the present study (Table 7). In a review, Theurer et al. (1999) noted an increase in milk and milk protein yields when SF corn was fed. However, Firkins et al. (2001) reported that milk protein percentage and milk yield were not different for $\mathrm{SF}$ versus $\mathrm{G}$ corn. The regression procedure used by the latter authors accounted for differences in DMI or 
other dietary factors rather than to total effect of grain processing attributed to starch digestibility.

Milk fat percentage was significantly decreased when SF corn replaced G corn (Table 7). Steam-flaking corn linearly increased apparent ruminal NSC digestibility (Table 3), which resulted in higher ruminal propionate concentrations in cows fed SF corn compared with G corn (Table 4). Decreased milk fat percentage can be explained by the glucogenic theory of milk fat depression for which increased propionate production causes metabolic changes that lead to decreased milk fat percentage (Gaynor et al., 1995). The lack of a corn effect on duodenal trans- $\mathrm{C}_{18: 1}$ flow (Table 6) does not support the theory of trans fatty acids in milk fat depression (Kalscheur et al., 1997) or is a result of our inability to differentiate trans isomers (as discussed earlier). Steam-flaking often depresses milk fat percentage (Theurer et al., 1999), although decreasing DMI associated with higher ruminal starch availability (as for SF vs. G corn diets) can help reduce the milk fat depression (Firkins et al., 2001).

As the level of WCS increased, there was a linear increase in MUN (Table 7). Gustafsson and Palmquist (1993) have shown a positive relationship between MUN and ruminal NH3 N concentration, which also increased linearly (Table 4). Similarly, the lower MUN concentration for SF corn than that for G corn paralleled a decreased ruminal $\mathrm{NH}_{3} \mathrm{~N}$ concentration with $\mathrm{SF}$ corn. Ekinci and Broderick (1997) and Dann et al. (1999) have also shown decreased MUN concentrations when processed grains were compared with those with a lower degree of processing.

\section{CONCLUSIONS}

Alfalfa silage can be replaced with WCS in low forage diets in the short term without adversely affecting DMI, milk production, and ruminal digestion, although efficiency of microbial protein synthesis might be reduced. Replacing G corn with SF corn is an effective means to increase ruminal nutrient digestibility, although the improvements for total tract digestibility are not as substantial. The lack of an interaction between corn source and level of WCS substitution suggests that WCS was equally effective in maintaining ruminal fermentation and digestibility in diets varying in ruminal starch availability. Replacing forage with WCS at up to $15 \%$ of dietary DM is a viable alternative for producers when forage quality or quantity is limiting. However, the long-term effects of feeding similar diets need further investigation.

\section{REFERENCES}

Abel-Caines, S. F., R. J. Grant, and S. G. Haddad. 1997. Whole cottonseeds or a combination of soybeans and soybean hulls in the diets of lactating dairy cows. J. Dairy Sci. 80:1353-1357.
Allen, D. M., and R. J. Grant. 2000. Interactions between forage and wet corn gluten feed as sources of fiber in diets for lactating dairy cows. J. Dairy Sci. 83:322-331.

Allen, M. S. 1997. Relationship between fermentation acid production in the rumen and the requirement for physically effective fiber. J. Dairy Sci. 80:1447-1462.

Allen, M. S. 2000. Effects of diet on short-term regulation of feed intake by lactating dairy cattle. J. Dairy Sci. 83:1598-1624.

Arieli, A. 1998. Whole cottonseed in dairy cattle feeding: a review. Anim. Feed Sci. Tech. 72:97-110.

Armentano, L., and M. Pereira. 1997. Measuring the effectiveness of fiber by animal response trials. J. Dairy Sci. 80:1416-1425.

Association of Official Analytical Chemists. 1990. Official Methods of Analysis. Vol. I. 15th ed. AOAC, Arlington, VA.

Bhatti, S. A., and J. L. Firkins. 1995. Kinetics of hydration and functional specific gravity of fibrous feed by-products. J. Anim. Sci. 73:1449-1458.

Bremner, J. M., and D. R. Keeney. 1965. Steam distillation methods for determination of ammonium, nitrate and nitrite. Anal. Chim. Acta 32:485-495

Callison, S. L., J. L. Firkins, M. L. Eastridge, and B. L. Hull. 2001. Site of nutrient digestion by dairy cows fed corn of different particle sizes or steam-rolled. J. Dairy Sci. 84:1458-1467.

Chaney, A. L., and E. P. Marbach. 1962. Modified reagents for determination of urea and ammonia. Clin. Chem. 8:130-132.

Chen, K. H., J. T. Huber, C. B. Theurer, R. S. Swingle, J. Simas, S. C. Chan, Z. Wu, and J. L. Sullivan. 1994. Effect of steam flaking of corn and sorghum grains on performance of lactating cows. J. Dairy Sci. 77:1038-1043.

Clark, P. W., and L. E. Armentano. 1993. Effectiveness of neutral detergent fiber in whole cottonseed and dried distillers grains compared with alfalfa haylage. J. Dairy Sci. 76:2644-2650.

Clark, P. W., and L. E. Armentano. 1997. Replacement of alfalfa neutral detergent fiber with a combination of nonforage fiber sources. J. Dairy Sci. 80:675-680.

Coppock, C. E., J. R. Moya, J. W. West, D. H. Nave, J. M. Labore, and C. E. Gates. 1985. Effect of lint on whole cottonseed passage and digestibility and diet choice on intake of whole cottonseed by Holstein cows. J. Dairy Sci. 68:1198-1206.

Dann, H. M., G. A. Varga, and D. E. Putnam. 1999. Improving energy supply to late gestation and early postpartum dairy cows. J. Dairy Sci. 82:1765-1778.

Ekinci, C., and G. A. Broderick. 1997. Effect of processing high moisture ear corn on ruminal fermentation and milk yield. J. Dairy Sci. 80:3298-3307.

Firkins, J. L. 1996. Maximizing microbial protein synthesis in the rumen. J. Nutr. 126:1347S-1354S.

Firkins, J. L. 1997. Effects of feeding nonforage fiber sources on site of fiber digestion. J. Dairy Sci. 80:1426-1437.

Firkins, J. L., M. L. Eastridge, N. R. St-Pierre, and S. M. Noftsger. 2001. Effects of grain variability and processing on starch utilization by lactating dairy cattle. J. Anim. Sci. 79 (E. Suppl.):E218 E238. Online. Available: http://www.asas.org/jas.

Gaynor, P. J., D. R. Waldo, A. V. Capuco, R. A. Erdman, L. W. Douglass, and B. B. Teter. 1995. Milk fat depression, the glucogenic theory, and trans- $\mathrm{C}_{18: 1}$ fatty acids. J. Dairy Sci. 78:2008-2015.

Griinari, J. M., B. A. Corl, S. H. Lacy, P. Y. Chouinard, K. V. V. Nurmela, and D. E. Bauman. 2000. Conjugated linoleic acid is synthesized endogenously in lactating dairy cows by $\Delta^{9}$-desaturase. J. Nutr. 130:2285-2291.

Gustafsson, A. H., and D. L. Palmquist. 1993. Diurnal variation of rumen ammonia, serum urea, and milk urea in dairy cows at high and low yields. J. Dairy Sci. 76:475-484.

Hall, M. B., B. A. Lewis, P. J. Van Soest, and L. E. Chase. 1997. A simple method for estimation of neutral detergent-soluble fiber. J. Sci. Food Agric. 74:441-449.

Harfoot, C. G., and G. P. Hazlewood. 1988. Lipid metabolism in the rumen. Pages 285-322 in The Rumen Microbial Ecosystem. P. N. Hobson, ed. Elsevier Applied Science, New York.

Harvatine, D. I., J. E. Winkler, M. Devant-Guille, J. L. Firkins, N. R. St-Pierre, B.s. Oldick, and M. L. Eastridge. 2002. Whole linted 
cottonseed as a forage substitute: Fiber effectiveness and digestion kinetics. J. Dairy Sci. 85:1976-1987.

Hoover, W. H. 1986. Chemical factors involved in ruminal fiber digestion. J. Dairy Sci. 69:2755-2766.

Jenkins, T. C. 1994. Regulation of lipid metabolism in the rumen. J. Nutr. 124:1372S-1376S.

Joy, M. T., E. J. DePeters, J. G. Fadel, and R. A. Zinn. 1997. Effects of corn processing on the site and extent of digestion in lactating cows. J. Dairy Sci. 80:2087-2097.

Kalscheur, K. F., B. B. Teter, L. S. Piperova, and R. A. Erdman. 1997. Effect of dietary forage concentration and buffer addition on duodenal flow of trans- $\mathrm{C}_{18: 1}$ fatty acids and milk fat production in dairy cows. J. Dairy Sci. 80:2104-2114.

Kerley, M. S., J. L. Firkins, G. C. J. Fahey, and L. L. Berger. 1985. Roughage content and particle size: Their effects on size reduction and fiber composition of particles passing through the gastrointestinal tract of sheep fed corncob-concentrate diets. J. Dairy Sci. 68:1363-1375.

Knowlton, K. F., B. P. Glenn, and R. A. Erdman. 1998. Performance, ruminal fermentation, and site of starch digestion in early lactation cows fed corn grain harvested and processed differently. J. Dairy Sci. 81:1972-1984.

Mooney, C. S., and M. S. Allen. 1997. Physical effectiveness of the neutral detergent fiber of whole linted cottonseed relative to that of alfalfa silage at two lengths of cut. J. Dairy Sci. 80:2052-2061.

National Research Council. 1989. Nutrient Requirements of Dairy Cattle. 6th rev. ed. Natl. Acad. Sci., Washington, DC.

National Research Council. 2001. Nutrient Requirements of Dairy Cattle. 7th rev. ed. Natl. Acad. Sci., Washington, DC.

Palmquist, D. L. 1995. Digestibility of cotton lint fiber and whole oilseeds by ruminal microorganisms. Anim. Feed Sci. Technol. $56: 231-242$

Pantoja, J., J. L. Firkins, M. L. Eastridge, and B. L. Hull. 1994. Effects of fat saturation and source of fiber on site of nutrient digestion and milk production by lactating dairy cows. J. Dairy Sci. 77:2341-2356.

Pires, A. V., M. L. Eastridge, J. L. Firkins, and Y. C. Lin. 1997. Effects of heat treatment and physical processing of cottonseed on nutrient digestibility and production performance by lactating cows. J. Dairy Sci. 80:1685-1694.

Plascencia, A., and R. A. Zinn. 1996. Influence of flake density on the feeding value of steam-processed corn in diets for lactating cows. J. Anim. Sci. 74:310-316.

Poore, M. H., J. A. Moore, T. P. Eck, R. S. Swingle, and C. B. Theurer. 1993a. Effect of fiber source and ruminal starch degradability on site and extent of digestion in dairy cows. J. Dairy Sci. 76:2244-2253.

Poore, M. H., J. A. Moore, R. S. Swingle, T. P. Eck, and W. H. Brown. 1993b. Response of lactating Holstein cows to diets varying in fiber source and ruminal starch degradability. J. Dairy Sci. $76: 2235-2243$

Russell, J. B. 1998. Strategies that ruminal bacteria use to handle excess carbohydrate. J. Anim. Sci. 76:1955-1963.

SAS. 1999. What's New in SAS Software for Version 7 and the Version 8 Developer's Release. SAS Inst., Cary, NC.
Slater, A. L., M. L. Eastridge, J. L. Firkins, and L. J. Bidinger. 2000. Effects of starch source and level of forage neutral detergent fiber on performance by dairy cows. J. Dairy Sci. 83:313-321.

St-Pierre, N. R., and L. R. Jones. 1999. Interpretation and design of nonregulatory on-farm feeding trials. J. Dairy Sci. 82(Suppl. 2):177-182.

Sukhija, P. S., and D. L. Palmquist. 1988. Rapid method for determination of total fatty acid content and composition of feedstuffs and feces. J. Agric. Food Chem. 36:1202-1206.

Swain, S. M., and L. E. Armentano. 1994. Quantitaive evaluation of fiber from nonforage sources used to replace alfalfa silage. J. Dairy Sci. 77:2318-2331.

Theurer, C. B., J. T. Huber, A. Delgado-Elorduy, and R. Wanderley. 1999. Invited review: Summary of steam-flaking corn or sorghum grain for lactating dairy cows. J. Dairy Sci. 82:1950-1959.

Tice, E. M., M. L. Eastridge, and J. L. Firkins. 1993. Raw soybeans and roasted soybeans of different particle sizes. 1. Digestibility and utilization by lactating cows. J. Dairy Sci. 76:224-235.

Tice, E. M., M. L. Eastridge, and J. L. Firkins. 1994. Raw soybeans and roasted soybeans of different particle sizes. 2. Fatty acid utilization by lactating cows. J. Dairy Sci. 77:166-180.

Ushida, K., B. Lassalas, and J. P. Jouany. 1985. Determination of assay parameters for RNA analysis in bacterial and duodenal samples by spectrophotometry. Influence of sample treatment and preservation. Reprod. Nutr. Dev. 25:1037-1046.

Van Nevel, C. J., and D. I. Demeyer. 1996. Influence of $\mathrm{pH}$ on lipolysis and biohydrogenation of soybean oil by rumen contents in vitro. Reprod. Nutr. Dev. 36:53-63.

Van Soest, P. J. 1994. Nutritional Ecology of the Ruminant. Cornell Univ. Press, Ithaca, NY.

Van Soest, P. J., J. B. Robertson, and B. A. Lewis. 1991. Methods for dietary fiber, neutral detergent fiber, and nonstarch polysaccharides in relation to animal nutrition. J. Dairy Sci. 74:35833597.

VandeHaar, M. J., H. F. Bucholtz, M. S. Allen, J. R. Allen, J. R. Black, R. S. Emery, C. J. Sniffen, and R. W. Beverly. 1992. Spartan Ration Evaluator/Balancer for Dairy Cattle. Michigan State Univ., East Lansing.

Weidner, S. J., and R. J. Grant. 1994. Altered ruminal mat consistency by high percentages of soybean hulls fed to lactating dairy cows. J. Dairy Sci. 77:522-532.

Weiss, W. P. 1993. Predicting energy values of feeds. J. Dairy Sci. 76:1802-1811.

Williams, C. H., D. J. David, and O. Iismaa. 1962. The determination of chromic oxide in feces samples by atomic absorption spectrophotometry. J. Agric. Sci. 59:381-385.

Wu, Z., O. A. Ohajuruka, and D. L. Palmquist. 1991. Ruminal synthesis, biohydrogenation, and digestibility of fatty acids by dairy cows. J. Dairy Sci. 74:3025-3034.

Yu, P., J. T. Huber, F. A. P. Santos, J. M. Simas, and C. B. Theurer. 1998. Effects of ground, steam-flaked, and steam-rolled corn grains on performance of lactating cows. J. Dairy Sci. 81:777-783.

Zinn, R. A., and F. N. Owens. 1986. A rapid procedure for purine measurement and its use for estimating net ruminal protein synthesis. Can. J. Anim. Sci. 66:157-166. 